\title{
Pembuatan Abon Ikan Untuk Peningkatan Nilai Tambah Hasil Tambak Ikan di Desa Songan, Kecamatan Kintamani, Bali
}

\author{
Ni Putu Jesika Novianti', Luh Putu Mahyuni' ${ }^{2}$ \\ ${ }_{1,2}$ Fakultas Ekonomi dan Bisnis, Universitas Pendidikan Nasional \\ *e-mail: putujesika60@gmail.com¹, mahyuniluhputu@undiknas.ac.id ${ }^{2}$
}

\begin{abstract}
Songan Village, Kintamani District is a village that has local potential, namely the large number of tilapia fish cultivators. However, the cultivators have been selling their harvest in the form of raw fish only. The relatively cheap price of raw fish cannot provide significant benefits to tilapia fish cultivators, so that innovation is needed to add the value by further processing it. Seeing this situation, it is necessary to hold training in processing tilapia fish into ready-to-eat food such as fish floss and in product packaging, in order to increase the selling value of tilapia fish. Making fish floss does not require a large cost, so it is easy to be applied by tilapia fish cultivators. Meanwhile, the selling value is relatively better than the selling value of raw fish. Problems in the field in this community service activity were explored through observation and interview methods. After the problems were identified, training preparations and socialization were carried out, then training on making fish floss and their packaging were conducted. This activity is succeeded in providing an understanding of the importance of increasing the added value of fish production by processing it into fish floss, providing skills in making floss and packaging. Subsequent service activities can be directed at efforts to assist the community in obtaining P-IRT permits, assisting sales through social media, and accompanying the next production innovation process, among others by trying various other flavours apart from those tested in current community service activities.
\end{abstract}

Keywords: Fish floss, Added value of tilapia fish production, Innovation in production, Innovation in packaging

\begin{abstract}
Abstrak
Desa Songan, Kecamatan Kintamani merupakan desa yang memiliki potensi lokal yaitu banyaknya pembudidaya ikan mujair dan oleh pembudidaya hanya dimanfaatkan dengan cara menjual hasil panennya berupa ikan mentah saja. Harganya yang relatif murah kurang bisa memberikan keuntungan yang signifikan terhadap pembudidaya ikan mujair, sehingga dibutuhkan inovasi untuk mengolahnya lebih lanjut. Melihat situasi semacam ini, maka perlu diadakan pelatihan pengolahan ikan mujair menjadi makanan siap saji seperti abon ikan dan pengemasan produk agar dapat meningkatkan nilai jual ikan mujair. Pembuatan abon ikan ini tidak memerlukan biaya yang besar, sehingga mudah untuk diaplikasikan oleh pembudidaya ikan mujair. Sementara nilai jualnya relatif lebih baik daripada nilai jual ikan mentah. Permasalahan di lapangan dalam kegiatan pengabdian ini digali melalui metode observasi dan wawancara. Setelah permasalahan berhasil diidentifikasi, dilakukan persiapan pelatihan dan sosialisasi, kemudian dilakukan pelatihan pembuatan abon ikan beserta pengemasannya. Kegiatan ini berhasil memberikan pemahaman akan pentingnya meningkatkan nilai tambah produksi ikan melalui pengolahannya menjadi abon ikan, memberikan keterampilan pembuatan abon ikan dan pengemasannya. Kegiatan pengabdian selanjutnya dapat diarahkan pada upaya mendampingi masyarakat dalam pengurusan ijin P-IRT, membantu penjualan melalui media sosial, dan mendampingi proses inovasi produksi berikutnya, antara lain dengan mencoba berbagai varian rasa lainnya selain yang diuji coba pada kegiatan pengabdian saat ini.
\end{abstract}

Kata kunci: Abon ikan, Nilai tambah ikan mujair, Inovasi produksi, Inovasi pengemasan

\section{PENDAHULUAN}

\subsection{Analisa situasi}

Desa Songan merupakan salah satu desa yang terletak di Kecamatan Kintamani, Kabupaten Bangli. Secara admistrasi Desa Songan terdiri dari 18 dusun yaitu Dusun Ulundanu, Dusun Alengkong, Dusun, Balingkang, Dusun Bantas, Dusun Batu Meyeh, Dusun Bukit Sari, Dusun Bukit Tungtung, Dusun Buluh, Dusun Dalem, Dusun Kayu Selem, Dusun Kayupadi, Dusun Kendal, 
Dusun Munduk Lantang, Dusun Peradi, Dusun Pulu, Dusun Serongga, Dusun Tabu, Dusun Yeh Panes. Dengan jumlah penduduk 12.003 jiwa, yang terdiri dari laki-laki: 6001 jiwa dan perempuan: 6002 jiwa. Adapun batas-batas desa adalah sebagai berikut. Sebelah Utara: Desa Belandingan, Sebelah Timur: Desa Tianyar, Sebelah Selatan: Desa Batur, Sebelah Barat: Desa Batur (songanb, 2020). Sementara jarak dari Desa Songan ke pusat Kota Kabupaten Bangli sekitar 25 $\mathrm{km}$, ditempuh dengan waktu 45 menit dengan kendaraan bermotor. Mata pencaharian masyarakat Desa Songan beragam dari pegawai negeri, petani, peternak, pedagang serta ibu rumah tangga.

Desa songan memiliki potensi yang dapat dikembangkan, salah satunya adalah pada sektor perikanan. Hal ini disebabkan karena sebagian besar wilayah Desa Songan merupakan wilayah danau batur yang dapat dimanfaatkan untuk membudidayakan ikan mujair. Masyarakat Desa Songan membudidayakan ikan mujair dengan sistem keramba. Keramba adalah wadah untuk memelihara ikan yang berupa jaring dan berbentuk segi empat yang diapungkan di dalam danau dan di permukaannya menggunakan pelampung dan kayu. Keramba atau keramba jaring apung berfungsi sebagai tempat untuk pemeliharan dan pelindung ikan dari serangan pemangsa dan segala gangguan lainnya. Masa panen ikan mujair yang dibudiyakan ini berkisaran antara empat sampai lima bulan.

Berdasarkan hasil observasi yang dilakukan di Desa Songan jumlah penduduk yang memiliki tambak ikan mujair tidaklah sedikit. Ketika musim panen telah tiba ikan mujair dijual berupa ikan mentahan saja tanpa ada pengolahan sama sekali dan dijadikan lauk pauk untuk makan sehari-hari, sehingga ikan mujair ini kurang memiliki nilai ekonomis dan keuntungan yang diperoleh sangat sedikit. Berdasarkan kondisi ini, maka pengolahan pasca panen ikan mujair sangat dibutuhkan agar dapat bertahan lebih lama dan dapat meningkatkan nilai jual. Maka solusi yang bisa dilakukan adalah dengan memberikan edukasi atau informasi kepada masyarakat sekitar mengenai pengolahan ikan mujair. Ikan mujair dapat diolah menjadi berbagai macam makanan siap saji seperti diolah menjadi abon ikan. Abon merupakan produk olahan yang sudah dikenal luas oleh masyarakat. Abon ikan adalah jenis makanan olahan ikan yang diberi bumbu, selanjutnya diolah dengan cara perebusan dan penggorengan (Wahida et al., 2020). Olahan ini menjadi salah satu solusi yang bisa dilakukan agar ikan mujair bisa bertahan lebih lama. Bahan baku yang mudah didapat dan peralatan yang dibutuhkan sederhana membuat usaha abon ikan ini tidak membutuhkan biaya yang besar. Abon ikan mujair ini juga dapat meningkatkan nilai jual ikan mujair. Kemudian memberikan pelatihan mengenai strategi pengemasan produk yang baik agar terlihat lebih menarik sehingga dapat menunjang penjualan.

Kegiatan pengabdian ini memiliki tujuan sebagai berikut:

1. Untuk meningkatkan pengetahuan dan keterampilan warga sekitar dalam mengolah hasil panen berupa ikan mujair agar dapat meningkatan nilai jual ikan mujair.

2. Memberikan pengetahuan tentang strategi pengemasan produk yang baik dan menarik agar dapat meningkan penjualan.

\subsection{Permasalahan Mitra}

a. Permasalahan dari sisi produksi

Permasalahan yang dihadapi oleh mitra sehubung dengan aspek produksi antara lain:

1. Ketika panen massal terjadi, harga ikan mujair cenderung lebih rendah dari harga biasanya.

2. Pengolahan ikan mujair menjadi produk siap saji seperti abon, belum dilakukan secara optimal.

3. Mitra belum memiiki kemampuan dan ketrampilan yang memadai untuk membuat abon ikan.

4. Mitra belum memiliki peralatan yang memadai untuk membuat abon ikan.

b. Permasalahan dari sisi manajemen

Mitra kurang mampu dalam melakukan strategi pengemasan yang baik dan menarik. 


\subsection{Permasalahan Prioritas yang Disepakati Bersama}

a. Aspek Produksi

1. Memberikan edukasi atau informasi kepada mitra mengenai pembuatan abon ikan.

2. Praktik membuat abon ikan.

b. Aspek Manajemen

Merancang kemasan produk abon ikan yang baik dan menarik.

\subsection{Kajian Literatur}

Ikan mujair merupakan salah satu ikan yang hidup di air tawar dan ikan mujair bisa konsumsi oleh manusia. Ikan memiliki banyak manfaat untuk tubuh manusia. Ikan merupakan salah satu sumber protein hewani yang sangat diperlukan oleh manusia, yaitu sebegai sumber energi, membantu dan memelihara pertumbuhan, mempertinggi daya tahan tubuh dari penyakit dan memperlancar proses fisiologis (Restu, 2016). Protein hewani adalah protein lengkap yang memiliki mutu tinggi karena memiliki kandungan asam amino yang diperlukan oleh tubuh. Kadar protein per $100 \mathrm{~g}$ ikan mujair adalah $20 \mathrm{~g}$ lebih tinggi dibandingkan telur sebesar $12,8 \mathrm{~g}$, daging ayam sebesar 18,2g serta daging sapi sebesar 18,8g (Widodo, 2018).

Pada prinsipnya usaha diversifikasi pengolahan hasil perikanan bertujuan untuk meningkatkan daya simpan hasil perikanan, memberikan beragam produk pilihan pada konsumen serta meningkatkan nilai jualnya sehingga akan meningkatkan pendapatan pengolah ikan (Muchtar et al., 2020). Ikan mujair dapat diolah menjadi abon. Abon merupakan produk olahan yang sudah dikenal luas oleh masyarakat. Abon ikan adalah jenis makanan olahan ikan yang diberi bumbu, selanjutnya diolah dengan cara perebusan dan penggorengan (Wahida et al., 2020).

Secara umum pengertian kemasan produk adalah suatu wadah ataupun pembungkus yang berfungsi untuk meminimalisir terjadinya kerusakan pada produk yang dikemas. Saat ini kemasan produk sudah menjadi hal yang sangat penting untuk diperhatikan. namun sesungguhnya kemasan bukan hanya pembungkus saja, karena kemasan memberikan kesan mendalam pada pandangan pertama yang membuat konsumen jatuh hati pada suatu produk yang kemudian memutuskan untuk membeli atau membatalkan pembelian (Apriyanti, 2018).

\section{METODE}

Metode kegiatan yang diterapkan untuk merealisasikan program kerja ini, yaitu:

\section{Observasi}

Metode observasi yang dilakukan dalam pengabdian ini adalah dengan menelusuri wilayah di sekitar Desa Songan khususnya di tepi danau batur. Dimana observasi ini bertujuan untuk mengidentifikasi potensi Desa Songan yang dapat dikembangkan dan mengidentifikasi masalah yang ada. Dari hasil observasi yang dilakukan diketahui potensi yang dapat dikembangkan di Desa Songan adalah pengolahan hasil panen tambak ikan mujair menjadi abon ikan.

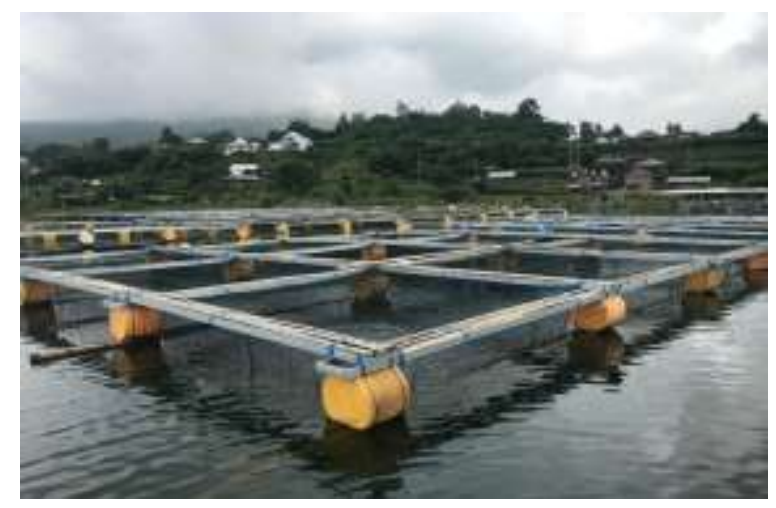

Gambar 1. Tambak ikan mujair 


\section{Wawancara}

Tidak hanya melakukan observasi saja, metode lainnya yang dilakukan dalam pengabdian ini adalah dengan melakukan wawancara bersama Ibu Jero Suci selaku salah satu pemilik tambak ikan mujair di Desa Songan. Wawancara ini dilakukan untuk mengetahui lebih lanjut permasalahan yang umumnya dihadapi oleh pembudidaya ikan mujair di Desa Songan. Setelah melakukan wawancara diketahui permasalahan yang ada adalah rendahnya harga ikan mujair karena pengolahan hasil panen ikan mujair belum dilakukan secara optimal. Setelah melakukan observasi dan wawancara dengan salah satu pemilik tambak ikan mujair untuk mencari solusi dari permasalahan yang selama ini dihadapi dibuat kesepakatan untuk mengolah hasil panen ikan mujair yang selama ini belum dilakukan secara optimal.

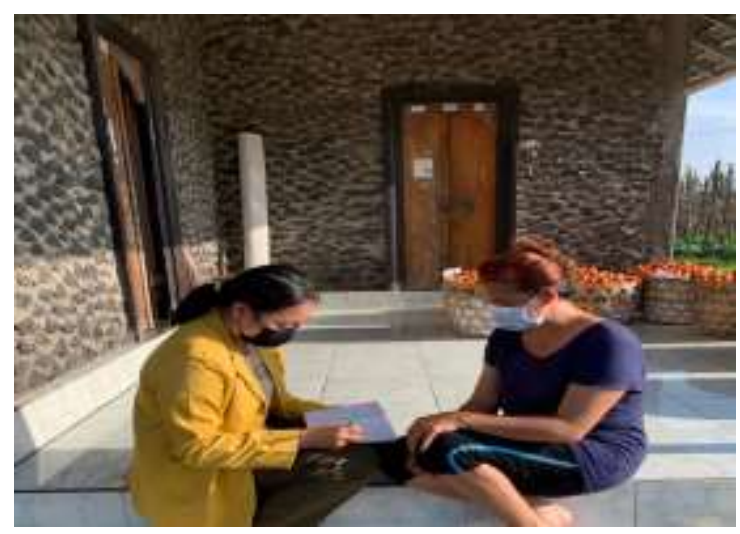

Gambar 2. Wawancara bersama Ibu Jero Suci

3. Perencanaan dan Persiapan

Perencanaan dan persiapan merupakan hal penting yang perlu dilakukan sebelum memulai sesuatu. Perencanaan dan persiapan yang dilakukan oleh mahasiswa adalah pemberian edukasi atau informasi kepada pembudidaya ikan mujair, menyiapkan alat dan bahan yang diperlukan untuk membuat abon ikan serta menyiapkan packaging yang akan digunakan untuk mengemas produk.

4. Praktik

Kegiatan praktik dimaksudkan untuk meningkatkan pemahaman dan keahlian masyarakat sasaran serta menumbuhkan rasa semangat untuk mengoptimalkan hasil panen ikan mujair yang ada di Desa Songan. Proses pembuatan abon ikan mujair meliputi beberapa tahapan, yaitu:

1. Menyiapkan alat dan bahan yang diperlukan. Adapun alat yang diperlukan adalah wajan, sendok, kompor gas, packaging, dll. Dan bahan yang diperlukan adalah ikan mujair, jahe, kunir, daun salam, bawang merah, bawang putih, cabai, kemiri, ketumbar, santan, garam, dan penyedap makanan.

2. Membersihkan ikan mujair yang akan dijadikan abon

3. Mengukus ikan mujair yang telah dibersihkan selama 10-15 menit

4. Penyortiran ikan mujair dengan tujuan memisahkan daging ikan dengan tulang ikan, kepala ikan dan kulit ikan.

5. Suwir-suwir daging ikan yang telah dipisahkan dengan tulang, kepala dan kulit ikan.

6. Haluskan bahan bumbu yang akan digunakan

7. Tumis bumbu sekitar 5-10 menit. Dalam menumis bumbu ini menggunakan santan yang telah disediakan

8. Masukan suwiran ikan mujair ke dalam bumbu yang ditumis, aduk rata dengan bumbu yang telah ditumis

9. Tunggu hingga 20-50 menit dan aduk rata

10. Apabila abon sudah matang angkat dari wajan dan diamkan di wadah hingga dingin

11. Abon ikan siap di packing. 

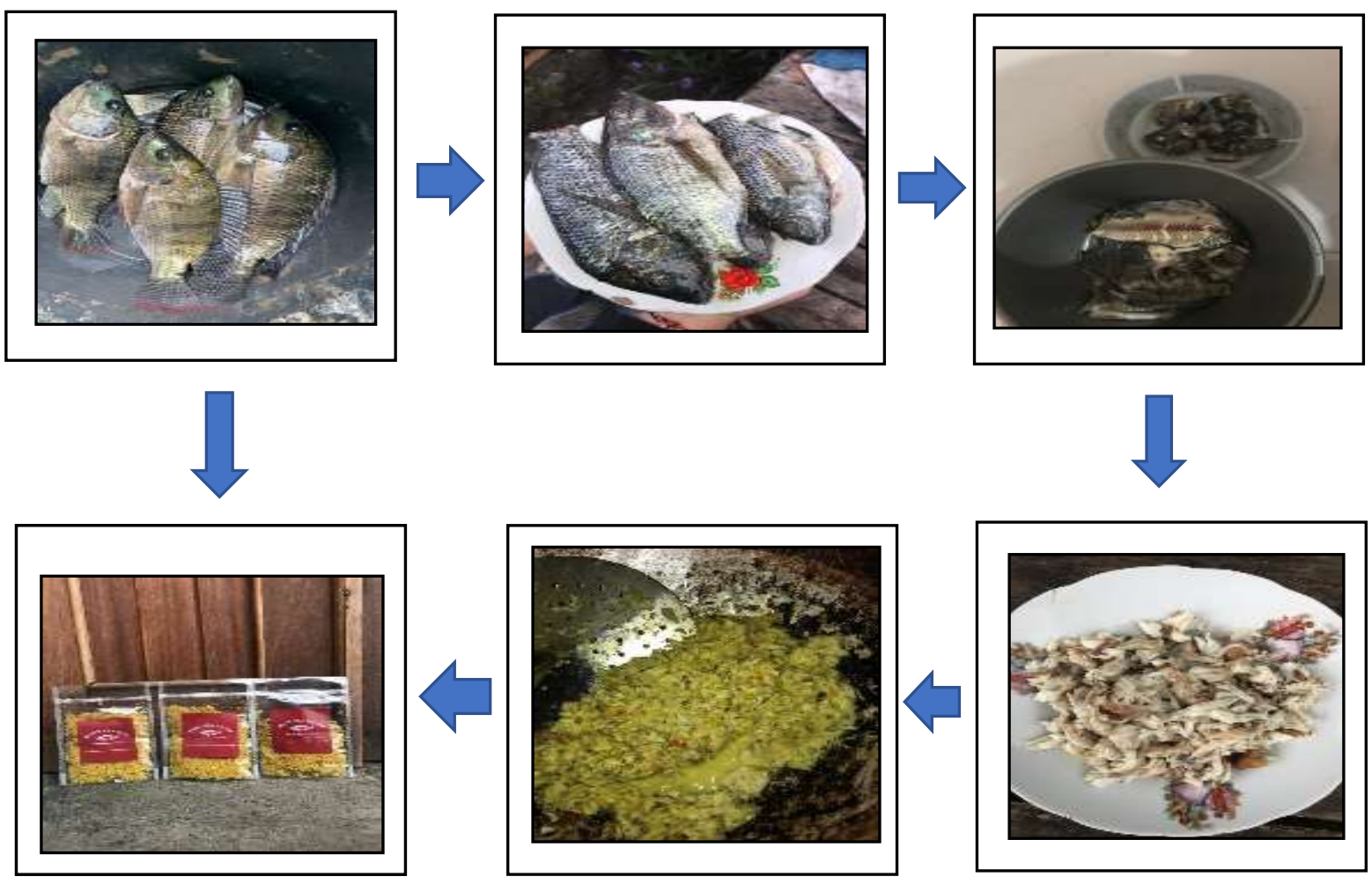

Gambar 3. Urutan kegiatan praktik

\section{HASIL DAN PEMBAHASAN}

Kegiatan pengabdian kepada masyarakat mengenai pembuatan abon ikan untuk peningkatan nilai jual hasil tambak ikan ini dilaksanakan di Desa Songan, Kecamatan Kintamani , Kabupaten Bangli dan kegiatan dapat dilaksanakan sesuai dengan timeline yang telah ditentukan. Berdasarkan tujuan dari kegiatan ini yaitu memberikan edukasi dan pelatihan kepada masyarakat Desa Songan khususnya pembudidaya ikan mujair serta pelatihan pengemasan produk yang dapat meningkatkan keterampilan pembudidaya ikan mujair dalam mengolah hasil panennya sehingga dapat meningkatkan nilai jual ikan mujair.

Rincian tahapan kerja yang sudah dilakukan antara lain:

\section{Pelatihan mengolah hasil panen tambak ikan mujair}

Dalam pelatihan mengolah hasil panen tambak ikan mujair ini dimulai dari pemberian edukasi dan informasi terkait dengan pengolahan ikan mujair menjadi abon ikan. Pada tahap ini mahasiswa memberikan edukasi dan informasi mengenai proses pembuatan abon ikan agar dapat meningkatkan nilai jual ikan mujair. Tahap selanjutnya mahasiswa bersama pembudidaya ikan mujair melakukan praktik pembuatan abon ikan mujair. Pembudidaya ikan mujair terlihat antusias dalam mengikuti pembuatan abon ikan. Dari pelatihan membuat abon ikan mujair ini menghasilkan produk siap saji berupa abon ikan mujair. Peserta mengikuti pembuatan abon sesuai dengan arahan dan peserta juga tertarik dalam mengikuti pelatihan ini, karena dalam pembuatan abon ikan ini tidak memerlukan biaya yang banyak. 


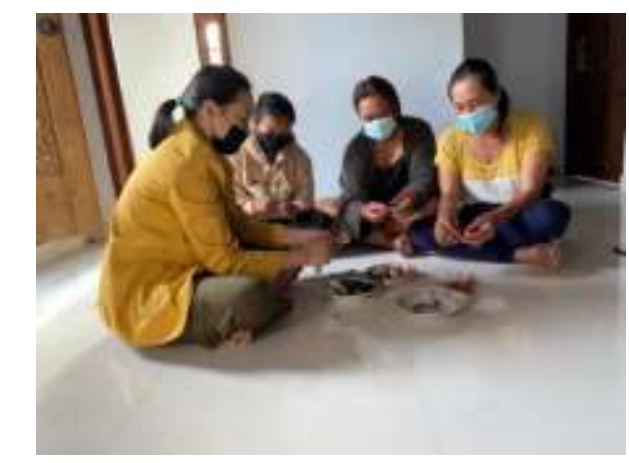

Gambar 4. Proses pembuatan abon ikan mujair

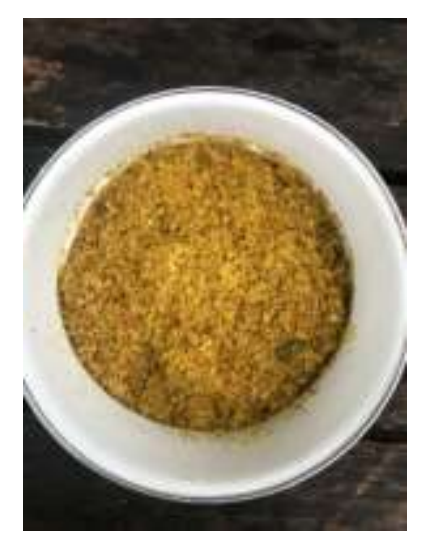

Gambar 5. Abon ikan mujair

2. Pelatihan pengemasan produk.

Setelah praktik membuat abon ikan mujair selesai dilanjutkan dengan praktik pengemasan produk. Pengemasan abon ikan mujair dilakukan sebagai upaya untuk menaikan daya jual abon ikan mujair. Suatu produk akan memiliki nilai tambah jika dikemas dengan baik dan menarik (Purnavita et al., 2018). Kemasan yang digunakan untuk produk abon ikan mujair ini berupa standing pouch yang di lengkapi dengan stiker label berwarna merah.

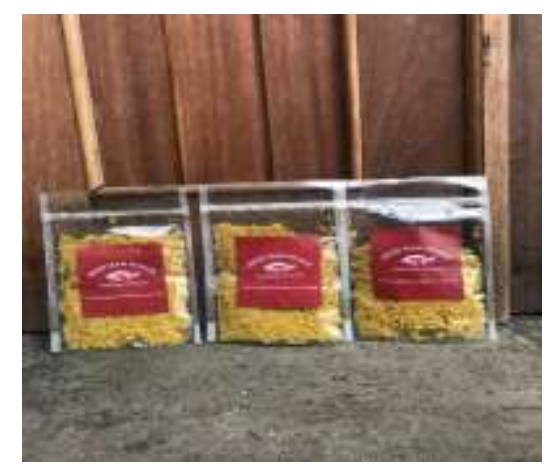

Gambar 6. Kemasan abon ikan mujair hasil pelatihan

\section{KESIMPULAN}

Dari kegiatan pengabdian kepada masyarakat yang berjudul Pembuatan Abon Ikan Untuk Peningkatan Nilai Tambah Hasil Tambak Ikan di Desa Songan, Kecamatan Kintamani ini dapat disimpulkan sebagai berikut : 
1. Program pelaksanaan Pembuatan Abon Ikan Untuk Peningkatan Nilai Tambah Hasil Tambak Ikan di Desa Songan, Kecamatan Kintamani ini berhasil dilaksanakan dalam mengembangkan potensi Desa Songan pada bidang peternakan atau perikanan.

2. Peserta pelatihan mendapatkan insight baru mengenai pengolahan ikan mujair menjadi abon ikan mujair.

3. Peserta pelatihan telah mampu memproduksi abon ikan mujair untuk meningkatkan nilai jual ikan mujair.

4. Peserta pelatihan mengetahui tentang strategi pengemasan produk sehingga produk abon ikan terlihat lebih menarik.

\section{DAFTAR PUSTAKA}

Apriyanti, M. E. (2018). Pentingnya Kemasan terhadap Penjualan Produk Perusahaan. Sosio EKons, 10(1), 20. https://doi.org/10.30998/sosioekons.v10i1.2223

Muchtar, F., Bahar, H., \& Lestari, H. (2020). Pemanfaatan Protein Hewani Melalui Pengolahan Nugget Ikan Tuna Di Desa Malalanda Kecamatan Kulisusu Kabupaten Buton Utara. Abdi Masyarakat, 2(1), 11-14. https://doi.org/10.36312/abdi.v2i1.1177

Purnavita, S., Sriyana, H. Y., \& Widiastuti, T. (2018). Kemasan Menarik dan Internet Marketing untuk Meningkatkan Nilai Jual Emping Garut sebagai Produk Unggulan Kabupaten Sragen. EDimas, 9(1), 88. https://doi.org/10.26877/e-dimas.v9i1.2260

Restu. (2016). Pengolahan Abon Ikan Karandang (Channa pleurophthalmus) dengan Penambahan Kelapa Parut. Jurnal Ilmu Hewani Tropika, 5(1), 22-26.

songanb, desa. (2020). Jumlah Penduduk. Desa Songanb. https://songanb.desa.id/first

Wahida, W., Sunarni, S., \& Widijastuti, R. (2020). Pelatihan Pembuatan Abon Ikan Gabus Di Kampung Sarmayam Indah Distrik Tanah Miring Kabupaten Merauke. Jurnal Marine Kreatif, 4(1), 21-26. https://doi.org/10.35308/jmk.v4i1.2453

Widodo, S. (2018). Analisis Pengaruh dan Perbaikan Status Gizi Siswa SD Dengan Intervensi Biskuit Berbasis Tepung Mujair. 1(April), 84-90. 